\title{
Leaching of cations in soil cultivated with sugarcane subjected to saline irrigation and leaching fractions
}

\author{
Raquele M. de Lira ${ }^{1}$, Leandro C. Gordin ${ }^{2}$, Ênio F. de F. e Silva ${ }^{2}$, \\ Gerônimo F. da Silva ${ }^{2}$, Daniel da C. Dantas ${ }^{2}$ \& José E. F. de Morais ${ }^{2}$ \\ ${ }^{1}$ Universidade Federal Rural de Pernambuco/Unidade Acadêmica de Serra Talhada/Departamento de Agronomia. Serra Talhada, PE. E-mail: \\ raquelelira@gmail.com (Corresponding author) - ORCID: 0000-0002-9035-7788 \\ ${ }_{2}^{2}$ Universidade Federal Rural de Pernambuco/Departamento de Engenharia Agrícola/Programa de Pós-Graduação em Engenharia Agrícola. Recife, PE. \\ E-mail: leandrocandidog@hotmail.com - ORCID: 0000-0002-6452-6007; enio.fsilva@ufrpe.br - ORCID: 0000-0002-8652-503X; agrogefe@yahoo.com.br \\ - ORCID: 0000-0002-3348-7252; d1cdantas@hotmail.com - ORCID: 0000-0002-2459-9877; joseedson50@hotmail.com - ORCID: 0000-0002-3641-2221
}

Key words:

Saccharum spp.

water salinity

soluble ions

\begin{abstract}
A B S T R A C T
The objective of this study was to evaluate the concentration of cations in the leachate of soil cultivated with sugarcane irrigated with brackish water. An experiment was carried out in drainage lysimeters at the Federal Rural University of Pernambuco, at the Recife campus. The experimental design was completely randomized in a $5 \times 2$ factorial scheme, with four replicates, corresponding to five levels of electrical conductivity of the irrigation water $(\mathrm{ECw})\left(0.5,2.0,3.5,5.0\right.$ and $\left.6.5 \mathrm{dS} \mathrm{m}^{-1}\right)$ and two leaching fractions $(\mathrm{LF} 1=0$ and $\mathrm{LF} 2=0.17)$ corresponding to water depths equivalent to 100 and $120 \%$ of crop evapotranspiration (ETc), by which the irrigations were managed. Electrical conductivity of the drained water was daily monitored and $\mathrm{Na}, \mathrm{K}, \mathrm{Ca}$ and $\mathrm{Mg}$ concentrations in the drainage water were determined at 129, 214, 286 and 324 days after planting (DAP). There were higher salt concentrations in the leachates when leaching fraction LF1 $=0$ was used. The use of the 0.17 leaching fraction led to greater dissolution of the salts and may have caused a higher uptake of the essential cations by the crop. Sodium was the most quantitatively leached cation at all collection dates.
\end{abstract}

\section{Palavras-chave:}

Saccharum spp.

salinidade da água

íons solúveis

\section{Lixiviação de cátions em solo cultivado com cana-de-açúcar submetida à irrigação salina e frações de lixiviação}

\section{R E S U M O}

Objetivou-se com o presente trabalho avaliar a concentração de cátions no lixiviado de solo cultivado com cana-de-açúcar irrigada com águas salobras. Realizou-se um experimento em lisímetros de drenagem na Universidade Federal Rural de Pernambuco, no campus do Recife. O delineamento experimental utilizado foi o inteiramente casualizado em esquema fatorial 5 $\mathrm{x} 2$, com quatro repetições, sendo cinco níveis de condutividade elétrica da água de irrigação (CEa) $\left(0,5 ; 2,0 ; 3,5 ; 5,0\right.$ e 6,5 dS m $\left.{ }^{-1}\right)$ e duas frações de lixiviação (FL1 = 0 e FL2 = 0,17) que corresponderam à lamina de irrigação equivalente a 100 e $120 \%$ da evapotranspiração da cultura (ETc), pelas quais foram manejadas as irrigações. Diariamente foi monitorada a condutividade elétrica da água drenada (CEad) e aos 129, 214, 286 e 324 dias após o plantio (DAP) foram determinadas as concentrações de $\mathrm{Na}, \mathrm{K}, \mathrm{Ca}$ e $\mathrm{Mg}$ na água de drenagem. Verificou-se maiores concentrações de sais na água drenada quando não se utilizou a fração de lixiviação, ou seja, $\mathrm{FL} 1=0$. O uso da fração de lixiviação 0,17 proporcionou maior dissolução dos sais podendo ter ocasionado maior absorção dos cátions essenciais pela cultura. $\mathrm{O}$ sódio foi o cátion quantitativamente mais lixiviado em todas as datas de coletas. 


\section{INTRODUCTION}

Soil salinization is an increasing problem on a global scale. It is a natural process of the weathering referred to as primary salinization, occurring over time; and anthropogenic, which is a process accelerated through irrigated agriculture, known as secondary salinization. Low-quality waters and poor irrigation management in poorly drained areas without using leaching fractions may intensify the reduction of soil production capacity (Lima Júnior \& Silva, 2010; Herbert et al., 2015).

Excess of salts in agricultural soils can cause serious damages to soil physical and chemical processes (lower availability of water and nutrients to plants, reduction in the osmotic potential of the soil solution and clay dispersion) and result in generalized reduction in plant growth (Vasconcelos et al., 2013). According to Puga et al. (2016), one of the techniques used to control salts in the soil is the use of leaching fraction, which consists in applying through irrigation a water depth above the need of the crop, so that salts from irrigation water and/or present in the soil are leached from the root zone, allowing good yields of the crops.

According to Silva et al. (2011), the main salts dissolved in irrigation water are the cations sodium, calcium, magnesium and potassium. However, each element has a different reaction in the soil-plant-atmosphere system, being totally dependent on the surrounding environment.

Thus, it is necessary to monitor nutrients and ions removed or retained in the soil or in the plants when low-quality waters are used, as a form of prevention of soil salinization and yield reduction. Therefore, this study aimed to evaluate the concentration of leached cations in soil cultivated with sugarcane subjected to irrigation with brackish waters and use of leaching fractions.

\section{MAterial AND Methods}

The experiment was carried out at the Lysimeter Station of Irrigated Agriculture Professor Ronaldo Freire de Moura, located at the Department of Agricultural Engineering (DEAGRI) of the Federal Rural University of Pernambuco

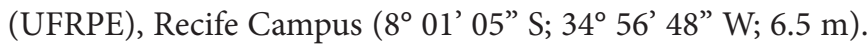
According to Köppen's classification, the climate of the region is As, tropical megathermal (humid tropical) (Alvares et al., 2014).

The experimental area comprised 40 drainage lysimeters with capacity for $1000 \mathrm{~L}$ each, with upper external diameter of $1.38 \mathrm{~m}$ and external height of $0.745 \mathrm{~m}$, equidistantly spaced by $1.20 \mathrm{~m}$ and installed at $0.65 \mathrm{~m}$ depth, with an edge of $10 \mathrm{~cm}$ above soil surface to avoid the entry of rainwater or irrigation water, from runoff.

The soil material used in the lysimeters came from a Spodosol of the municipality of Goiana/PE (0 to $0.40 \mathrm{~m})$ : EC = $0.38 \mathrm{dS} \mathrm{m}^{-1}$, coarse sand $=640 \mathrm{~g} \mathrm{~kg}^{-1}$, fine sand $=250 \mathrm{~g} \mathrm{~kg}^{-1}$, silt $=30 \mathrm{~g} \mathrm{~kg}^{-1}$, clay $=80 \mathrm{~g} \mathrm{~kg}^{-1}$, textural class $=$ sand, bulk density $=1.80 \mathrm{~kg} \mathrm{dm}^{-3}$, particle density $=2.63 \mathrm{~kg} \mathrm{dm}^{-3}$, clay dispersed in water $=0 \%$, degree of flocculation $=100 \%$, moisture $_{0.33 \mathrm{~atm}}=$ $3.02 \%$, moisture ${ }_{15 \text { atm }}=1.34 \%$, available water $=1.68 \%$, organic matter $=20.39 \mathrm{~g} \mathrm{~kg}^{-1}, \mathrm{pH}_{(\mathrm{H} 2 \mathrm{O})}=5.0, \mathrm{P}=5 \mathrm{mg} \mathrm{dm}^{-3}, \mathrm{~K}^{+}=$ $0.02 \mathrm{cmol} \mathrm{dm}_{c}^{-3}, \mathrm{Ca}^{2+}=0.30 \mathrm{cmol}_{c} \mathrm{dm}^{-3}, \mathrm{Mg}^{2+}=0.40 \mathrm{cmol} \mathrm{dm}_{c}^{-3}$, $\mathrm{Na}^{+}=0.11 \mathrm{cmol}_{\mathrm{c}} \mathrm{dm}^{-3}, \mathrm{Al}^{3+}=0.75 \mathrm{cmol}_{c} \mathrm{dm}^{-3}, \mathrm{CEC}_{\text {effective }}=$ $1.58 \mathrm{cmol}_{\mathrm{c}} \mathrm{dm}^{-3}, \mathrm{SB}=0.83 \mathrm{cmol}_{\mathrm{c}} \mathrm{dm}^{-3}$, determined according to the methodology of EMBRAPA $(2009,2011)$.

The internal drainage system of the lysimeters was composed of a 50-mm-diameter low-density polyethylene tube, covered with a geotextile. The lysimeters were filled with a 7-cm layer of $19-\mathrm{mm}$ crushed stone, covered with a geotextile to prevent soil particles from passing. Above the geotextile, the lysimeters were filled with soil and each lysimeter received the same amount of dry soil $(1070 \mathrm{~kg})$.

Treatments consisted of the combination of five levels of irrigation water electrical conductivity $(\mathrm{ECw})$ : $\mathrm{T} 1=0.5$; $\mathrm{T} 2=2.0 ; \mathrm{T} 3=3.5 ; \mathrm{T} 4=5.0$ and $\mathrm{T} 5=6.5 \mathrm{dS} \mathrm{m}^{-1}$ and two leaching fractions $(\mathrm{L} 1=0$ and $\mathrm{L} 2=0.17)$, corresponding to water depths equivalent to $\mathrm{L} 1=100 \%$ and $\mathrm{L} 2=120 \%$ of crop evapotranspiration (ETc), respectively. The experimental design was completely randomized in a $5 \times 2$ factorial scheme, with four replicates, totaling 40 experimental plots.

Salinity levels were obtained by the addition of $\mathrm{NaCl}$ and $\mathrm{CaCl}_{2}$ at equivalent proportion of 1:1 (Ca:Na), respectively, in water from the local supply system of the UFRPE (ECw $=0.5 \mathrm{dS} \mathrm{m}^{-1}$ ) in amounts necessary to obtain the electrical conductivities of the respective treatments, according to Rhoades et al. (2000) (Eq. 1):

$$
\mathrm{Q}=640 \mathrm{EC}_{\mathrm{w}}
$$

where:

Q - quantity of salts $\left(\mathrm{mg} \mathrm{L}^{-1}\right)$; and

$\mathrm{ECw}$ - desired value of water electrical conductivity $\left(\mathrm{dS} \mathrm{m}^{-1}\right)$.

For the control (T1), only water from the local supply system was used. The sugarcane variety RB867515 was used in the experiment, and its cuttings came from the Sugarcane Experimental Station of Carpina (EECAC-UFRPE). Planting was carried out at spacing of $1.20 \mathrm{~m}$ between rows and $0.20 \mathrm{~m}$ between cuttings, with two buds each.

Sugarcane was planted on August 2, 2014. Treatments began to be applied at 60 days after planting (DAP) and irrigation was daily performed, based on the replacement of $100 \%$ and $120 \%$ ETc according to Eq. 2 :

$$
\mathrm{ETc}=\mathrm{ETo} \mathrm{Kc}
$$

where:

ETc - crop evapotranspiration, $\mathrm{mm} \mathrm{d}^{-1}$;

ETo - reference evapotranspiration, $\mathrm{mm} \mathrm{d}^{-1}$; and

Kc - crop coefficient, dimensionless.

ETo was determined from the meteorological data collected at the automatic meteorological station (Campbell Scientific, CR1000/CFM100/OS100) situated in the area and used in the Penman-Monteith estimation method (Allen et al., 1998). The Kc used varied with the phenological stage, according to the Food and Agricultural Organization of the United Nations FAO (Allen et al., 1998). 
Every day, an $80-\mathrm{mL}$ aliquot was collected in the water drained from the $120 \%$ ETc water depth to monitor the concentration of leached salts, by measuring the electrical conductivity $(\mathrm{ECdw})$ with a benchtop conductivity meter (Model MCA150). For the 100\% ETc water depth, drainage only occurred when the daily effective rainfall was higher than ETc. At 129, 214, 286 and 324 DAP, the cations calcium, magnesium, potassium and sodium were analyzed in the leachate according to the methodology of EMBRAPA (2011).

The data were subjected to analysis of variance by $\mathrm{F}$ test $(\mathrm{p}$ $<0.05)$ and regression analysis for salinity levels, and means were compared by Tukey test $(\mathrm{p}<0.05)$, using the statistical program Sisvar (Ferreira, 2014).

\section{Results AND Discussion}

Until 94 DAP, the drained water showed mean electrical conductivity below $3 \mathrm{dS} \mathrm{m}^{-1}$, due to the effect of dilution of the salts caused by the rainfall observed in the period (Figure 1).

From this period (94 DAP), ECdw increased for all ECw levels studied, and these increments were directly

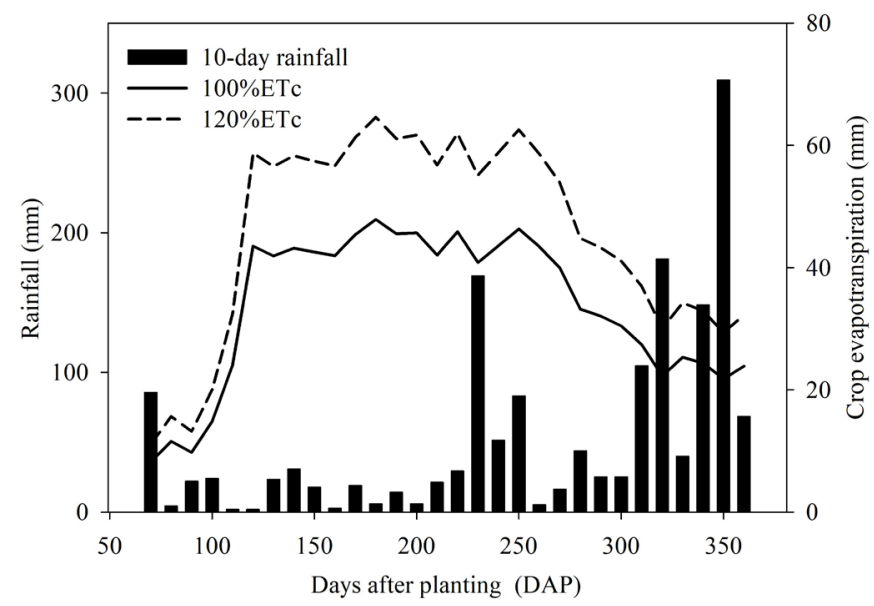

Figure 1. Rainfall and crop evapotranspiration recorded along the experiment

proportional to the ECw values. This occurred because of the increase in irrigation depth due to the higher ETc over the time, in which a drier period was observed up to 220 DAP (Figure 2).
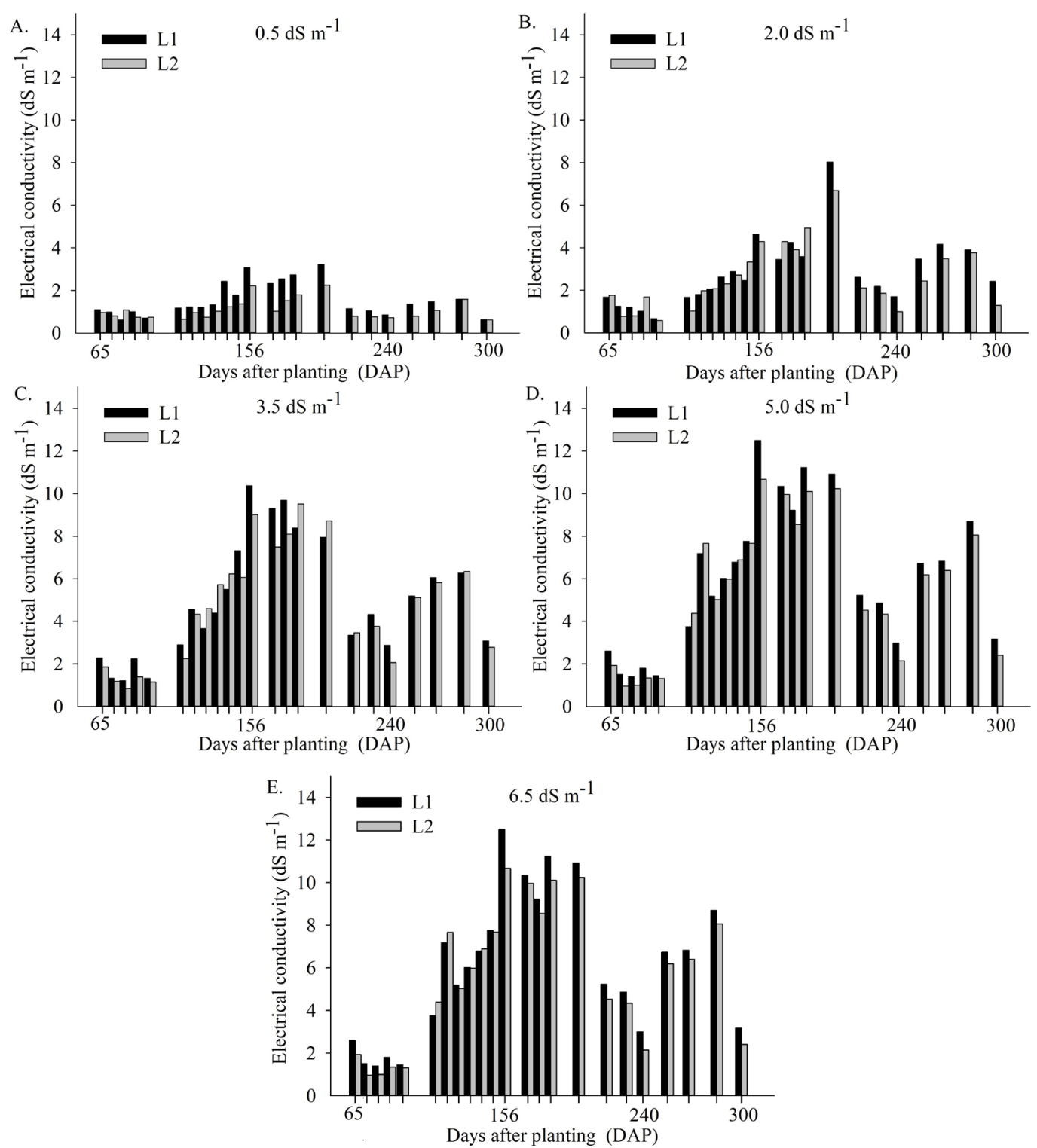

Figure 2. Electrical conductivity of the water drained from the lysimeters as a function of levels of irrigation water salinity: 0.5 (A); 2.0 (B); 3.5 (C); 5.0 (D); 6.5 (E) dS $\mathrm{m}^{-1}$ and leaching fractions ( $\mathrm{L} 1=0$ and $\mathrm{L} 2=0.17$ ) along the sugarcane cycle 
From 94 DAP, it was also observed that most treatments under 0.17 leaching fractions had lower values of ECdw (Figure 2), proving the effect of leaching fraction on the reduction of soil salinity, corroborating the results obtained by Simões et al. (2016).

This occurred because a water depth above the requirement of the crop was applied, leading to leaching of salts from the root zone, higher dissolution of salts and consequently favoring higher absorption of nutrients by the plant.

The leaching fraction L1 did not cause drainage every day and salts accumulated in the soil, being only leached when effective rainfall occurred. Ferreira et al. (2006), evaluating the beet crop irrigated with brackish water of different levels of electrical conductivity (1, 2, 3 and $\left.4 \mathrm{dS} \mathrm{m}^{-1}\right)$ and applying leaching fractions equivalent to $0.25,0.50,0.75,1.00$ and 1.25 of the pore volume of the soil, observed increments of salinity in the leachate as the leaching fractions decreased.
In terms of electrical conductivity of drained water, it was also observed that salinity decreased in some periods of analysis, due to the intense rains occurred in the period. In addition, there was higher conductivity at $156 \mathrm{DAP}\left(\mathrm{ECw} \sim 14 \mathrm{dS} \mathrm{m}^{-1}\right)$ at the most saline level and 100\% ETc replacement (Figure 2).

For the concentrations of $\mathrm{Na}, \mathrm{K}, \mathrm{Ca}$ and $\mathrm{Mg}$ salts in the drained water, there were isolated effects of both factors irrigation water salinity and leaching fractions. In the last analysis at 324 DAP, none of the factors had significant effect on the variables, except sodium, which was influenced by irrigation water salinity (Table 1 ).

As irrigation water salinity increased, all cations were leached with increments according to the regression equations presented for each element and date in Figure 3.

For all ions analyzed at 214 DAP, there was greater leaching of the salts, probably because the period was drier; thus, more

Table 1. Summary of test $\mathrm{F}$ of the leached cations as a function of levels of irrigation water salinity and leaching fractions

\begin{tabular}{|c|c|c|c|c|c|c|c|c|c|}
\hline Source of variation & DF & $\mathrm{Ca}_{129 D A P}$ & $\mathrm{Ca}_{214 D A P}$ & $\mathrm{Ca}_{286 D A P}$ & $\mathrm{Ca}_{324 D A P}$ & $\mathrm{Mg}_{129 D A P}$ & $\mathrm{Mg}_{214 \mathrm{DAP}}$ & $\mathrm{Mg}_{286 D A P}$ & $\mathrm{Mg}_{324 \mathrm{DAP}}$ \\
\hline ECw (S) & 4 & 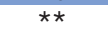 & $\star \star$ & $\star \star$ & ns & 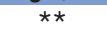 & $\star \star$ & $\star \star$ & ns \\
\hline Fraction (LF) & 1 & ** & ** & ** & ns & ** & $0.0013^{*}$ & ** & ns \\
\hline $\mathrm{ECW} \times \mathrm{LF}$ & 4 & ns & $4^{\text {ns }}$ & ns & ns & ns & ns & ns & ns \\
\hline CV (\%) & & 4.81 & 16.94 & 14.88 & 30.65 & 20.96 & 11.94 & 11.51 & 42.19 \\
\hline & & $\overline{K_{129 D A P}}$ & $\overline{K_{214 D A P}}$ & $\overline{K_{286 D A P}}$ & $\overline{K_{324 D A P}}$ & $\mathrm{Na}_{129 D A P}$ & $\mathrm{Na}_{214 \mathrm{DAP}}$ & $\mathrm{Na}_{286 \mathrm{DAP}}$ & $\mathrm{Na}_{324 \mathrm{DAP}}$ \\
\hline ECw (S) & 4 & $\star \star$ & $\star \star$ & $\star \star$ & ns & $\star \star$ & $\star \star$ & $\star \star$ & $\star \star$ \\
\hline Fraction (LF) & 1 & ** & ** & ** & ns & * & ** & ** & ns \\
\hline $\mathrm{ECW} \times \mathrm{LF}$ & 4 & ns & ns & ns & ns & ns & ns & ns* & ns \\
\hline CV (\%) & & 21.20 & 17.21 & 9.29 & 73.17 & 12.93 & 15.94 & 14.49 & 34.47 \\
\hline
\end{tabular}

*Significant at 0.05 probability level ** Significant at 0.01 probability level; ns Not significant
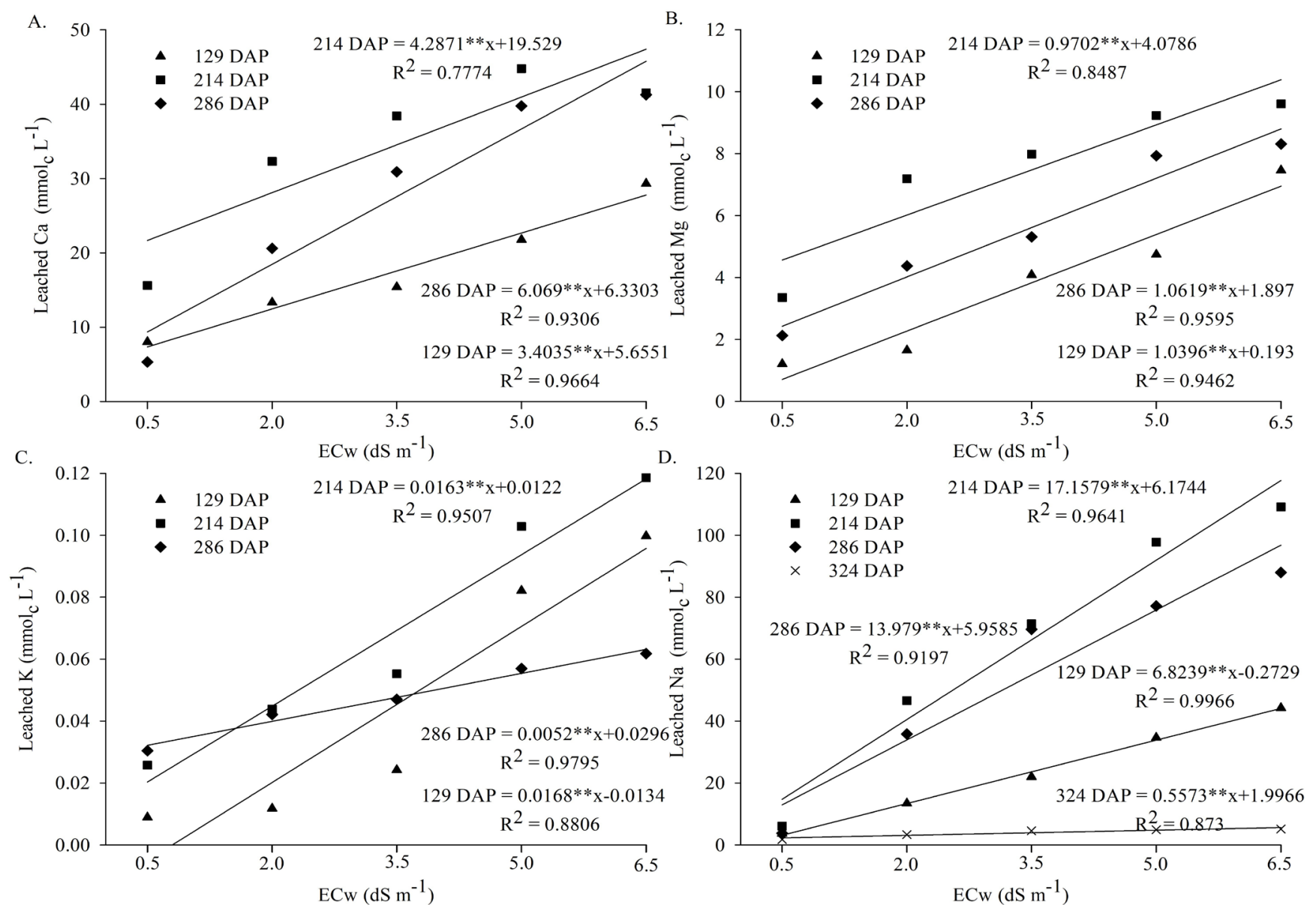

Figure 3. Concentrations of calcium (A), magnesium (B), potassium (C) and sodium (D) leached in the water drained from the lysimeters 
Table 2. Comparison of means for the leached cations considering the factor leaching fraction (LF)

\begin{tabular}{|c|c|c|c|c|c|c|c|c|}
\hline \multirow{2}{*}{$\begin{array}{c}\text { Source } \\
\text { of variation }\end{array}$} & $\mathrm{Ca}_{129 D A P}$ & $\mathrm{Ca}_{214 \mathrm{DAP}}$ & $\mathrm{Ca}_{286 \mathrm{DAP}}$ & $\mathbf{C a}_{324 D A P}$ & $\mathrm{Mg}_{129 \mathrm{DAP}}$ & $M g_{214 D A P}$ & $\mathrm{Mg}_{286 \mathrm{DAP}}$ & $\mathrm{Mg}_{324 \mathrm{DAP}}$ \\
\hline & \multicolumn{8}{|c|}{$\mathrm{mmol}_{\mathrm{c}} \mathrm{L}^{-1}$} \\
\hline LF1 & $18.4982 \mathrm{a}$ & $36.2052 \mathrm{a}$ & $28.304 \mathrm{a}$ & $4.0207 \mathrm{a}$ & $4.1704 \mathrm{a}$ & $7.9738 \mathrm{a}$ & $6.1820 \mathrm{a}$ & $0.9211 \mathrm{a}$ \\
\hline LF2 & $16.6362 \mathrm{~b}$ & $32.8613 b$ & $26.840 \mathrm{~b}$ & $3.5813 \mathrm{a}$ & $3.4929 \mathrm{~b}$ & $6.9747 \mathrm{~b}$ & $5.0450 \mathrm{~b}$ & $0.8236 \mathrm{a}$ \\
\hline \multirow[t]{3}{*}{ LSD } & 0.5456 & 1.5467 & 0.8687 & 0.9978 & 0.5186 & 0.5762 & 0.4174 & 0.2658 \\
\hline & $K_{\text {129DAP }}$ & $\mathrm{K}_{214 \mathrm{DAP}}$ & $\mathrm{K}_{286 \mathrm{DAP}}$ & $\mathrm{K}_{324 \mathrm{DAP}}$ & $\mathrm{Na}_{\text {129DAP }}$ & $\mathrm{Na}_{214 D A P}$ & $\mathrm{Na}_{286 \mathrm{DAP}}$ & $\mathrm{Na}_{324 \mathrm{DAP}}$ \\
\hline & \multicolumn{8}{|c|}{$\mathrm{mmol}_{\mathrm{G}} \mathrm{L}^{-1}$} \\
\hline LF1 & $0.0618 \mathrm{a}$ & $0.0800 \mathrm{a}$ & $0.0517 \mathrm{a}$ & $0.0443 \mathrm{a}$ & $22.8809 \mathrm{~b}$ & $71.1536 \mathrm{a}$ & $57.1128 \mathrm{a}$ & $4.4544 \mathrm{a}$ \\
\hline LF2 & $0.0288 \mathrm{~b}$ & $0.0585 b$ & $0.0435 b$ & $0.0365 \mathrm{a}$ & $24.3404 \mathrm{a}$ & $61.3004 \mathrm{~b}$ & $52.6583 b$ & $3.4400 \mathrm{a}$ \\
\hline LSD & 13.17 & 0.0077 & 0.0028 & 0.0167 & 1.3722 & 2.5418 & 1.5917 & 1.1336 \\
\hline
\end{tabular}

LSD - Least significant difference. Means followed by the same letters in the column do not differ statistically by Tukey test at 0.05 probability level

irrigation with salinized water was applied and probably plants had more difficulty absorbing nutrients. According to Munns \& Tester (2008), composts of $\mathrm{Ca}^{2+}, \mathrm{K}^{+}, \mathrm{Na}^{+}$and $\mathrm{Cl}^{-}$when added to the soil reach the roots, decreasing the osmotic potential of the soil-plant system, compromising the absorption of water and nutrients by the plant.

The first phase is fast because it occurs immediately after the contact with salinity, referred to as osmotic phase, in which salts such as $\mathrm{Ca}^{2+}, \mathrm{K}^{+}, \mathrm{Na}^{+}$and $\mathrm{Cl}^{-}$reach the roots, reducing the osmotic potential of the soil-plant system, compromising water absorption by the plant.

In the present study, potassium was the cation with lowest concentration in the leachate. Similar result was found by Pessoa et al. (2010), who worked with onion and three levels of electrical conductivity of the irrigation water $(0.2 ; 0.7$ and $2.0 \mathrm{dS} \mathrm{m}^{-1}$ ) and also observed that potassium was the cation present in lowest concentration in the water drained from the soil, but it increased as ECw increased. This probably occurred because this element does not participate significantly in the chemical composition of the irrigation water since, when water salinity is increased, there is a reduction in potassium content in the soils due to the replacement of this element in the exchange complex, especially when there are high concentrations of sodium (Deinlein et al., 2014), with subsequent leaching. The same result was observed for magnesium, which was also not supplied by the irrigation water and its contents increased in the leachates of the treatments with highest ECdw values (Figure 3).

Calcium was the essential element with greatest losses, with increment in concentration as ECw increased; however, its contents were surpassed by those of sodium ions.

High concentration of sodium in the irrigation water led to higher concentration in the drained water. This result was also found by Pessoa et al. (2010). Silva et al. (2008) also observed high sodium concentrations in the water drained from four soils irrigated with saline water in Rio Grande do Norte, and its concentrations were higher than those of magnesium and calcium, at 30 days of saline water application. Studying the contribution of irrigation with sodium-chlorine saline waters, Fernandes et al. (2009) also observed high sodium concentration in the soil of an irrigated perimeter in the Sertão region of Pernambuco.

In general, for all elements there was a similar behavior in terms of leaching fraction, with high concentration in the leachate at the leaching fraction $\mathrm{L} 1=0$, except for the sodium ion in the first analysis at 129 DAP, which had higher concentration at the leaching fraction $\mathrm{L} 2=0.17$ (Table 2), with mean value of $24.34 \mathrm{mmol} \mathrm{L}_{c}^{-1}$. This fact may have occurred due to the leaching of salts to the deeper layers and the lack of absorption of this element by plants, resulting from the very high concentration in the soil solution. Martinez et al. (2010) claim that, when irrigation is performed with levels above those tolerated by the crop and with water exceeding its requirement (leaching fraction), there is a miscible displacement of the solutes through diffusion, dispersion and mass flow, transporting them to deeper regions of the root zone.

Benites et al. (2009) claim that, comparing three essential elements present in the drainage water and evaluated in this study (calcium, magnesium and potassium), the highest mobility was related to the $\mathrm{K}^{+}$ion, followed by $\mathrm{Mg}^{2+}$, and the least mobile was $\mathrm{Ca}^{2+}$. Nevertheless, Ishiguro et al. (1992) already claimed that the higher the concentration of the nutrient in the soil solution, the greater the chance for it to be lost by leaching. Potassium preferentially moves by diffusion and at lower proportion by mass flow, whereas calcium and magnesium move preferentially by mass flow. In addition, potassium is at higher concentration in the plant, compared with calcium and magnesium. Mengel \& Kirkby (2001) claim that, although calcium concentration in the soil solution is ten times higher than that of potassium, its absorption will be usually lower than that of potassium by the plant.

\section{Conclusions}

1. The use of 0.17 leaching fraction allowed higher dissolution of the salts in the soil solution and may have allowed higher absorption of cations by the crop.

2. Increasing irrigation water salinity led to increment in the concentrations of the leached cations.

3. Sodium was the most quantitatively leached cation in the entire crop cycle.

\section{ACKNOWLEDGMENT}

To the Science and Technology Support Foundation of Pernambuco (FACEPE), to the Coordination for the Improvement of Higher Education Personnel (CAPES) for granting the Postgraduate scholarship and to the National Council for Scientific and Technological Development (CNPq/INCTsal) for the financial support.

\section{Literature Cited}

Allen, R. G.; Pereira, P. S.; Raes, R.; Smith, M. Crop evapotranspiration: Guidelines for computing crop water requirements. Rome: FAO, 1998. 300p. Irrigation and Dranaige Paper, 56 
Alvares, C. A.; Stape, J. L.; Sentelhas, P. C.; Gonçalves, J. L. M.; Sparovek, G. Köppen's climate classification map for Brazil. Meteorologische Zeitschrift, v.22, p.711-728, 2014. https://doi. org/10.1127/0941-2948/2013/0507

Benites, V. de M.; Carvalho, M. C.; Resende, A. V. de; Polidoro, J. C.; Bernardi, A. C. C.; Oliveira, F. A. de. O potássio, o cálcio e o magnésio na agricultura brasileira. In: Prochnow, L. I.; Casarin, V. (ed.) Boas práticas para uso eficiente de fertilizantes. 1.ed. Piracicaba: IPNI Brasil, 2009. Cap.16, p.100-130.

Deinlein, U.; Stephan, A. B.; Horie, T.; Luo, W.; Xu, G.; Schroeder, J. I. Plant salt-tolerance mechanisms. Trends in Plant Science, v.6, p.371-379, 2014. https://doi.org/10.1016/j.tplants.2014.02.001

EMBRAPA - Empresa Brasileira de Pesquisa Agropecuária. Manual de análises químicas de solos, plantas e fertilizantes. 2.ed. Brasília: Embrapa Informação Tecnológica, 2009. 627p.

EMBRAPA - Empresa Brasileira de Pesquisa Agropecuária. Manual de métodos de análise de solo. 2.ed. Rio de Janeiro: Embrapa Solos, 2011.212p.

Fernandes, J. G.; Freire, M. B. G. S.; Cunha, J. C.; Galvíncio, J. D.; Corrêa, M. M.; Santos, P. R. Qualidade físico-química das águas utilizadas no Perímetro Irrigado Cachoeira II, Serra Talhada, Pernambuco. Revista Brasileira de Ciências Agrárias, v.4, p.27-34, 2009. https://doi.org/10.5039/agraria.v4ila5

Ferreira, D. F. Sisvar: A guide for its bootstrap procedures in multiple comparisons. Ciência e Agrotecnologia, v.38, p.109-112, 2014 https://doi.org/10.1590/S1413-70542014000200001

Ferreira, P. A.; Moura, R. F.; Santos, D. B.; Fontes, P. C. R.; Melo, R. F. Efeitos da lixiviação e salinidade da água sobre um solo salinizado cultivado com beterraba. Revista Brasileira de Engenharia Agrícola e Ambiental, v.10, p.570-578, 2006. https:// doi.org/10.1590/S1415-43662006000300006

Herbert, E. R.; Boon, P.; Burgin, A. J.; Neubauer, S. C.; Franklin, R. B.; Ardón, M.; Hopfensperger, K. N.; Lamers, L. P. M.; Gell, P. A global perspective on wetland salinization: Ecological consequences of a growing threat to freshwater wetlands. Ecosphere, v.6, p.1-43, 2015. https://doi.org/10.1890/ES14-00534.1

Ishiguro, M.; Song, K. C.; Yuita, K. Ion transport in an Allophanic Andisol under the influence of variable charge. Soil Science Society of America Journal, v.56, p.1789-1793, 1992. https://doi. org/10.2136/sssaj1992.03615995005600060022x
Lima Júnior, J. A.; Silva, A. L. P. Estudo do processo de salinização para indicar medidas de prevenção de solos salinos. Enciclopédia Biosfera, v.6, p.1-21, 2010.

Martinez, M. A.; Silva, J. B. G.; Pereira, D. R. Modelagem do movimento de sais no solo. In: Gheyi, H. R.; Dias, N. da S.; Lacerda, C. F. de. Manejo da salinidade na agricultura: Estudos básicos e aplicados. Fortaleza: INCT Sal, 2010. Cap.7, p.93-113.

Mengel, K.; Kirkby, E. A. Principles of plant nutrition. 5.ed. Dordrecht: Kluwer Academic, 2001. 673p. https://doi.org/10.1007/978-94010-1009-2

Munns, R.; Tester, M. Mechanisms of salinity tolerance. Annual Review of Plant Biology, v.59, p.651-681, 2008. https://doi. org/10.1146/annurev.arplant.59.032607.092911

Pessoa, L. G. M.; Oliveira, E. E. M.; Freire, M. B. G. S.; Freire, F. J.; Miranda, M. A.; Santos, R. L. Composição química e salinidade do lixiviado em dois solos cultivados com cebola irrigada com água salina. Revista Brasileira de Ciências Agrárias, v.5, p.406-412, 2010. https://doi.org/10.5039/agraria.v5i3a573

Puga, A. P.; Melo, L. C. A.; Abreu, C. A.; Coscione, A. R.; Paz-Ferreiro, J. Leaching and fractionation of heavy metals in mining soils amended with biochar. Soil and Tillage Research, v.164, p.25-33, 2016. https://doi.org/10.1016/j.still.2016.01.008

Rhoades, J. D.; Kandiah, A.; Mashali, A. M. Uso de águas salinas para produção agrícola. Campina Grande: UFPB, 2000. 117p.

Silva, I. N.; Fontes, L. O.; Tavella, L. B.; Oliveira, J. B.; Oliveira, A. C. Qualidade de água na irrigação. Agropecuária Científica no Semiárido, v.7, p.1-15, 2011.

Silva, M. O.; Freire, M. B. G. S.; Mendes, A. M. S.; Fernandes, M. B.; Oliveira, D. A. Composição do lixiviado de quatro solos do Rio Grande do Norte irrigados com águas salinas. Revista Caatinga, v.21, p.189-203, 2008.

Simões, W. L.; Yuri, J. E.; Guimarães, M. J. M.; Santos, J. E. dos; Araújo, E. F. J. Beet cultivation with saline effluent from fish farming. Revista Brasileira de Engenharia Agrícola e Ambiental, v.20, p.62-66, 2016. https://doi.org/10.1590/1807-1929/agriambi.v20n1p62-66

Vasconcelos, R. R. A. de; Barros, M. de F. C.; Silva, Ê. F. de F. e; Graciano, E. S. A.; Fontenele, A. J. P. B.; Silva, N. M. S. da. Características físicas de solos salino-sódicos do semiárido pernambucano em função de diferentes níveis de gesso. Revista Brasileira de Engenharia Agrícola e Ambiental, v.17, p.1318-1325, 2013. https://doi.org/10.1590/S1415-43662013001200010 